Portland State University

PDXScholar

\title{
A series of landscape studies in oil painting and other media exploring and interpreting natural landscape elelments with emphasis on the relationship between plastic space and visual space
}

Eugene Neal Olson

Portland State University

Follow this and additional works at: https://pdxscholar.library.pdx.edu/open_access_etds Let us know how access to this document benefits you.

\section{Recommended Citation}

Olson, Eugene Neal, "A series of landscape studies in oil painting and other media exploring and interpreting natural landscape elelments with emphasis on the relationship between plastic space and visual space" (1966). Dissertations and Theses. Paper 318.

https://doi.org/10.15760/etd.318

This Thesis is brought to you for free and open access. It has been accepted for inclusion in Dissertations and Theses by an authorized administrator of PDXScholar. Please contact us if we can make this document more accessible: pdxscholar@pdx.edu. 
Eugene Neaz oleon for the inster of sclarioe in Ieaching in Art

Dete thesis is presented $\frac{\text { Jely } 21196.6}{0}$

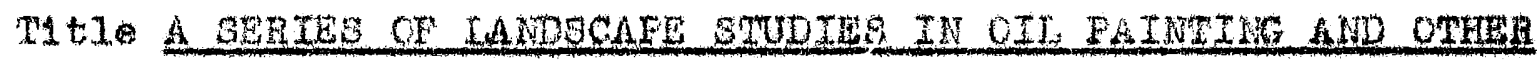

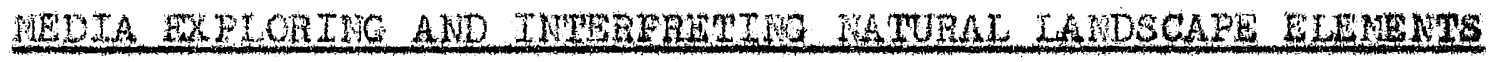

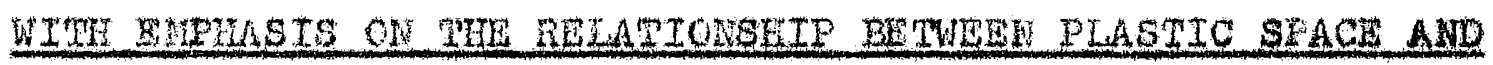
VISUA, SPACE

Abatract approved

In working with peintings dealing with the interpretation of landscape in oid part end mixed media durine the past year. I have seen now postabilities. This is true both of my approson to landgoape pointing and of the handising of the painting materials. These stuales have led me to a freer handing of point. Ir addition, they have led to to bo able to make more unlversal statement conoerning landscape Itself rather than onity a visul representation of one perticular landsoapo.

The first incleation the andversal statent about Indscape could be achleved becane apparent to we while I was working with mixed redla. The natural sction of one nedium upon the other very often suegests landscape forms which the artist can clarify into a statenent about landsone. Using the paint itgeif to develop a motif endeles 


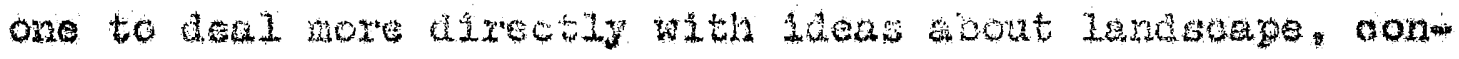

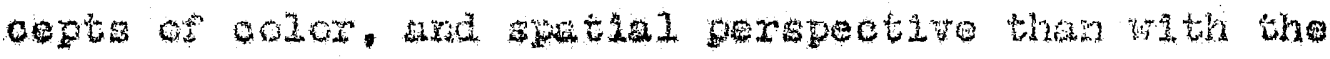

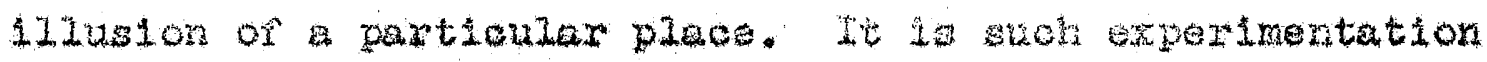
as that that led me toware whet I belleve to be a unirersal statement about Iandscape.

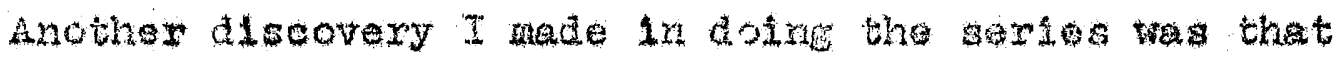
011 pant could be havdled 1 ratoh the same namer a

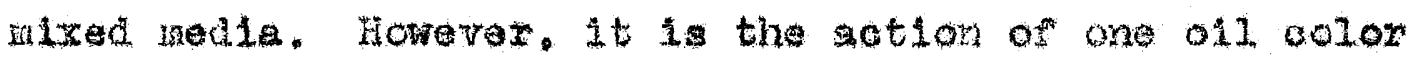
apon another wile in a Iiquid state that bocmes the means of augsesting foras. It is the mythule novenent of these forros and oolors that reflects the oonstant ohang Ind and movement of naturs. To ne this is the esseases the natural landoape and that whioh brinzs 1160 to 1 .

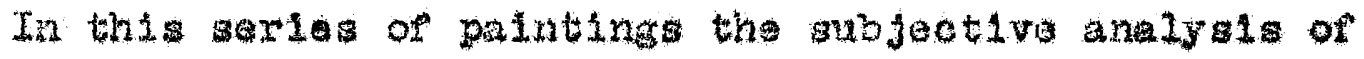
nature Inevitably aropped the objective detalis of the real Iandsoape. one's attentlon beglns to be centered on the

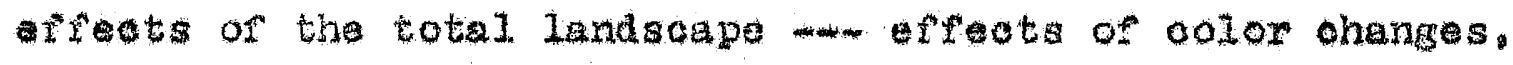

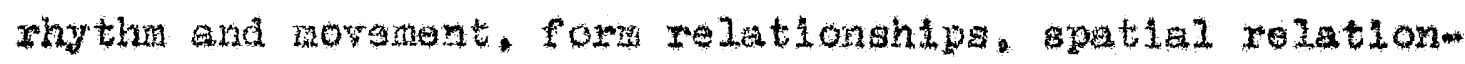
shipa. and atmosphare affects. wenta that are to be found

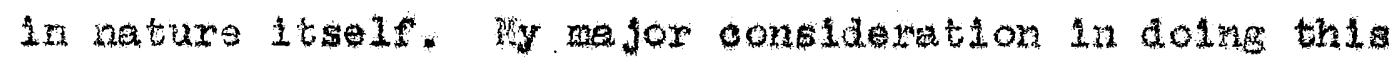

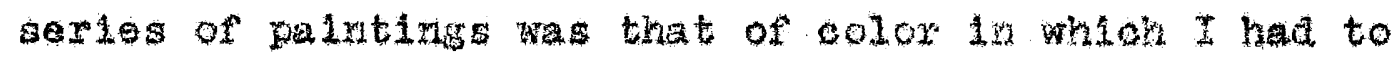
decla rhich colors would best sult the total impression I sought and groress quatio spece as well.

A majow disoovexy for me we that of the difference between wah palnting and brush painting. In brush palnting Ideas are songhat changed work prowesses but, general-

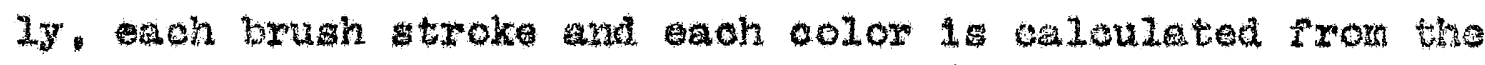




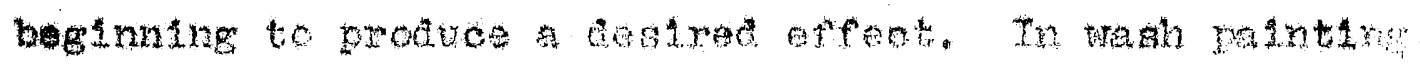

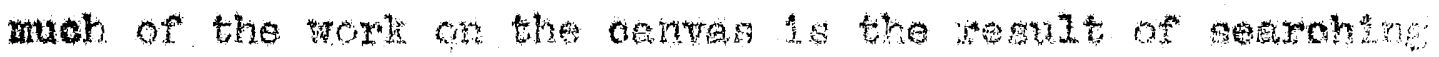

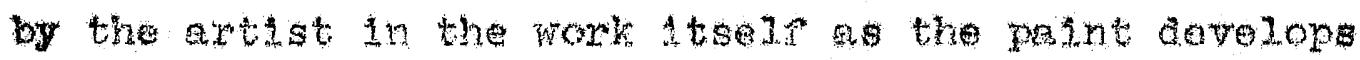
natura I forns on the cantas. The paint and the artist are one. so to spers, thtis cestain rorine appeat that the axtst feeld he ost work fron. It is et tha pont that he tekes over with the bxush and fully captorizes on the dovelopins fortis.

I belleve that color play a nor folo in involving the wlewer enotionally and intellectuajly in a patinting. It seems to me that pert of the rold of the artist is to

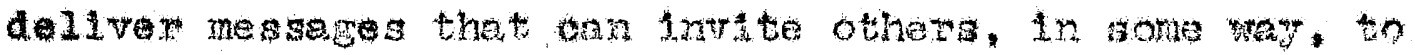
whare h1s feeling about the nature of things. For this reason he must saek ataterent that tull havo a wniversal expresiston so that he mey commanicate thith othera. Thls I have triod to do. 
A SERIES OF LANDSCAPE STUDIES IN OIL PAINTING AND OTHER MEDIA EXPLORING AND INTERPRETING

NATURAL LANDSCAPE ELENENTS WITH EMPHASIS

ON THE RELATIONSHTP BETWERN PLASTIC

SPACE AND VISUAL SPACE

by

EUGENE NEAL OLSON

THESIS REPORT

submltted to

PORTLAND STATE COLLEGE

in partial fulpiliment of

the requirements for the

degree of

MASTER OF SCIENCE IN TEACHING

August 1966 
APPROVED:

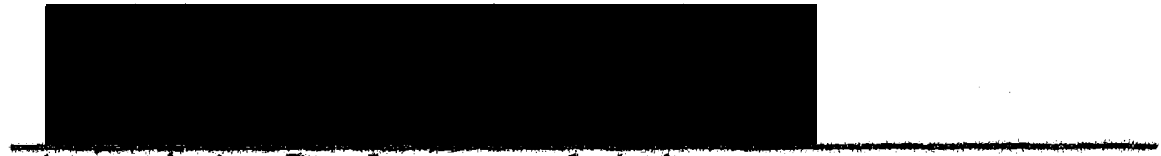

Assoelate Professor of Axt

In Charge of Major
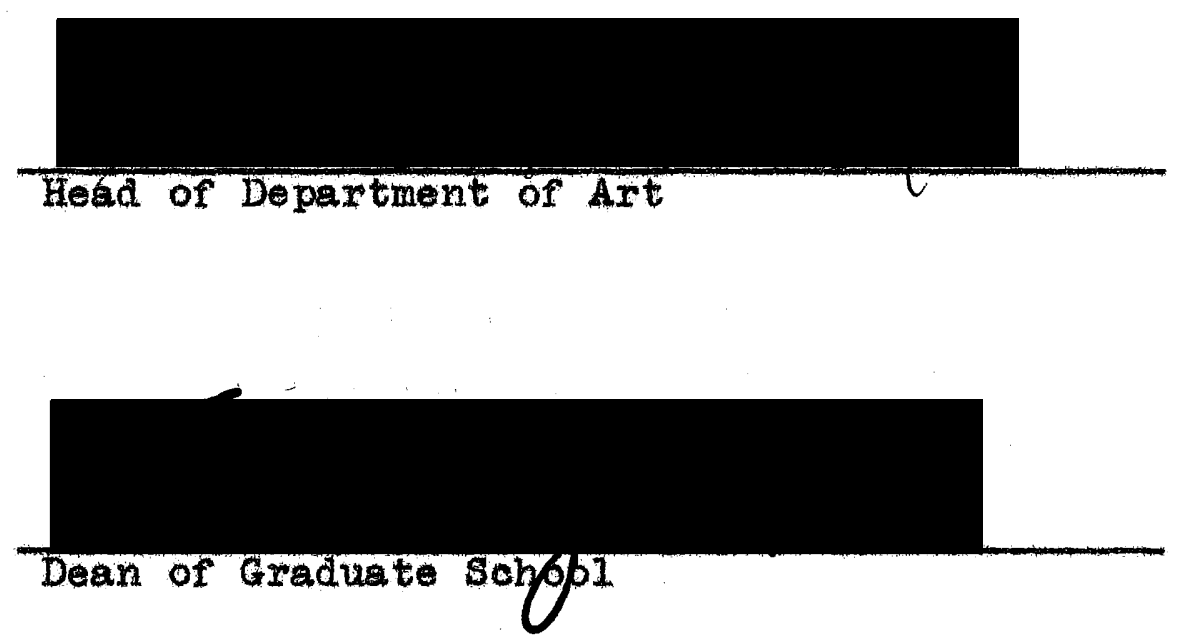

Date thesis 1 presented they 01,66

Typed by Sa11y A. Larson 
I. Thesis Report .......................... 1

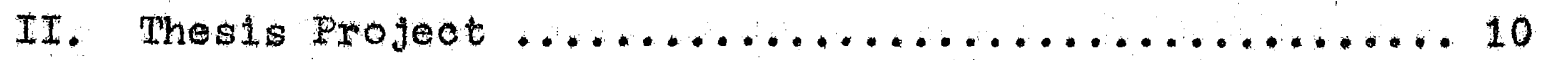

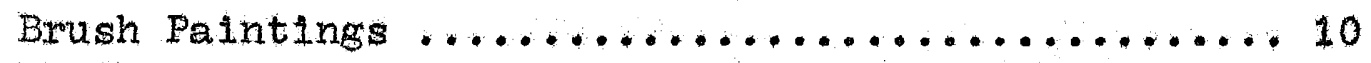

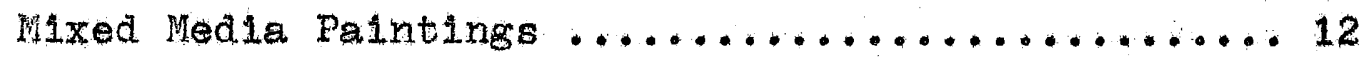

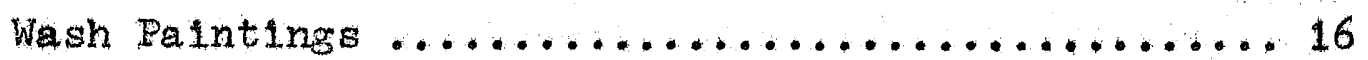




\section{A SERIES OF LANDSCAPE STUDIES IN OIL PAINTING AND OTHER MEDIA EXPLORIMG AND INTERPRETING NATURAL LANDSCAPE ELEWENS WTTH EMPHASIS ON THE RELATIONSHIP BETWEEN PLASTIC SFACE AND VISUAL SPACE}

In working with the paintings conoerned with the inter pretation of landscape in oll paint and mixed media during the past year. I have seen new possibilities. This is true of both my appoach to landscape painting and to the handling of the painting materials. My thesis, a painting project, is concerned with the interpretation of landscape from diverse points of view. These studies have led me to a freer handling of paint. In addition. they have led me to be able to make a more universal statement oonoerning landscape 1tself rather than only a visual representation of one particular landscape. A mountain scene speaks of mountains; a tree speaks of trees; and a mountain stream speaks of mountain streams. Always the universality of a motif is stressed. Yet to arrive at the universal I began wth the perticular. studying particular locations in the local land scape.

The flrst painting in this series was exeouted from studies made on location in the Columbia Gorge, a view of the oregon side of the gorge from Washington just west of Hood River. (See page 10, a). No other painting in the series is so strongly limited to suoh an exact looation. It was during work on this painting that I began to develop new Ideas about the nature of landscape painting: that more could be stated about landscape than whatever oould be 
sald about a partleular scene. After this new insight, the series that developed was not concerned with copying landsoape but rather with an attempt to find an equivalence to the universals in nature stated in terms of 011 paint.

The first indication that aniversal statement could be achleved became apparent while I was working with mixed modia. Combining ink, tempera, and pastel proved to be a sufflolent method of obtaining suggested landsape forms. The natural aetion of one medium upon the other causes elther blending of the media or a rejection of one by the other. If rejedtion oocurs, a line is generaliy formed. separating the two media. Thls line very of ten suggests landscape whioh the artist can clarify into a statement about landscape. Using the paint 1 tself as a means of developing 1deas bout landsoape outs down the rellance of working directly from partioular motif. Also, this enables the artist to deal nore directiy with ldeas about landscape. conoepts of color, and spatial perspective than with the 111usion of particular place. It is such experimentation as this that led me to be able to make what $I$ belleve to be a more universal statement about landscape.

Another discovery I made in dolng the serles was that ol1 paint could be handled in much the same manner as mixed med1a. However. Instead of the action of one medium on the other as in the mixed media. it is the ation of one oll oolor upon nother while in liquid state that becomes the 
means of strgesting forms. The subtle blending of colors on the oanvas when liquid palnts run together achleves infincte varleties of color mixtures not attainable with the bmush. It is this blending of colors that oreates an indistinetiveness between forms to the point where there is no visable separation of earth and sky. This seems to add Vitality to the inting. It is brought to iffe by the thythmlc movement and counter-movement of the forms and oolors. It I this aspeot that refleots the constant changIng and movement of nature. To me this is the essence of the natural landsoape and that whloh brings Iffe to it.

Chinese Iandseape painters such as M Fel and Fan K'uan of the Sung Period aspired after the spirlt of Iife in their work. The Chinese all 14 chl1, and it is their flrst anon of painting. The lm of their painting was to how the manifestation of the splrit residing in each and every form. If the painting ald not reveal some indieation of the spirit (chly), the forms were considered ilfeless. They also ndeavore to find in their art that spontaneous ease by which an inspiration of the moment might be expressed fully and naturally when the technical means have been mastered. It was this Chinese theory that prompted me to searoh for a way of capturing nature so that the paintings would be allve and visually moving. I

The Chinese palnters of the sung Perlod were not the only palnters in history who sought a unlversal statement of Iandsoape. Inoluded ate cave dwellers, Leonardo

Davino1, John Cozons, and Twentioth Century palnters. 
In this series of paintings the subjective analysis of nature inevitably loses the objeotive detalls of the real landscape. Trees and bushes are only suggested grass blades, stones, and pebbles are deemed too small to be seen In a moment's glanoe at a landscape. The onstantly changIng pattern of clouds and haze make them hard for an objective application in paint. Mountains and plains become large forms, but not detalled forms. Attention begins to center on effects as the total landscepe develops in the mind - - effects of oolor changes, rhythm and movement, form relationships, spatial relationships, and atmospheric effects. How each effect can be interpreted separately for Its importance and yet be unified into a whole statement is the problem each painting has to solve. The first consideration was that of color. What is the total impression sought -.. the hot, arid mountains of Eastern oregon or the cool canyons in the Columbia Gorge? The total inpression limited the beginning palette to colors that express the desired effect. Thus, hot colors were used for the desert, warm colors for the plains and barren mountain slopes. Cool colors were used for the cool mountain areas and cold colors for the deep recesses of mountain streams and canyons. It is relatively easy to decide whether the total impression desired is to be warm or cool and then to decide what warm or cool colors to use. In most of the paintings I chose colors that reminded me of the colors I 
might find at just such an actual looation. From thete I tried to develop varlations of those oolors, sometines bold variations and sometines subtle variations. Liquid paints running together were Instrumental in achieving the many variations of oolor. Plastio space was laxgely achleved with oolor rather than Itnear perspective. Colors, when placat upon surfaco, actully seem to have a spatial dimension. In general warm oolors seam to advance and cool. oolors seem to repede. The character of such effects, however, my be altered by diferences in intenstty and size relationships. High intenst ty colors tend to move forward of Lower intonsity oolors. This is beoaude the eyo is tralned to visualize spetial perspective in this mannor in a real landsope. Colors olose to the viewer are of a higher intenslty than those in the distance. The lowering of Intensity is oaused by the density of the atmosphere. The alr donsty not ondy lowers the intenstey of color but appears to change the colox, henoe, green trees may appear blue of even blue violot in the distance. This blutng omused by the density of the alf effects all the oolors. They become less intense or gradually change hue. Therefore, it is important to andyze each painting for its own method of showing or intimating spatial perspective. What is true in on patnting is not lways true in another. In the brush paintings recession in space is defined by golng from warm to cool oolors, yellow to green to blue. The high intensity color, as in the Columbia Gorge soene. 
Is mantained in the sky area to preserve the honesty of the two-dimensional surface.

In both the wash and brush paintings the size relationships help define space. Generally, there are larger objects or color areas in the foreground and smaller objects or color areas in the background. This is asy for the eye to understand sinoe this is the way objects are perceived in visual space. When looking aoross a landscape, trees (or any object) become progresslvely larger the closer they are to the viewer. Also, objects close to the viewer appear nearer his feet simply bocause that is where the ground goes. It follows, then, that large objects or forms near. the bottom of a picture would give the illusion of being closer, and small objects and forms at the top of the plcture would appear to be in the distance.

It will be noticed that the mingling of the Ilquid paints caused a haziness between color areas. It is hard. for me to suggest the hazy nature of atmosphere in a brush painting because of the hard edge a brush makes when it applies paint to canvas. Therefore, the hazy nature of atmosphere was better achieved in wash paintings. For this reason I felt that a truer statement about landscape was made in this medium. Also, the results of the wash paintIngs show more vitality because of the spontaneity of technique. The careful selection and application of the brush paintings appear as labored as the production of them was. However, both typer of painting technique are. 
In reality, oatefuliy worked out. The difference between the two techniques, brush and wash. is in the point at whioh deolisions are made as to what the composition of the peintIns w11 be. There are two different approaches to the landscape problem involved. The scheme of the brush paintings is pretty much ooncelved before work is begun. Some 1deas are ohanged as worls progresses, but generally each brush stroke and each oolor is calculated from the beginning to produo a destrod efect.

Wash paintine require alferent approach altogether. Finoh of the work on the canvas is the result of searching by the artist and the characteristio of the paint to develop natural forms on the canvas by itself. The paint's ability to flow produoes natural forms not attainable by brush strokes. Once familtar with the flow of the paint, the artist can begin to control it for desired effects whout impinging on its natural qualities. The palnt and the artist are one, so to speak, unt1 certain forms appear that the artist feels he car work from. xt is at this point that the artist takes over th the brush and fully develops the ideas already before him. Dry brugh techniques are applied. and the structure of the palinting is clarified.

In the brush paintings Iine is alluded to by color edge meeting color edge which is a less obvious use of line but, nevertheless, strong statement of line. There is no doubt where earth ends and sly beging or here tree onds and 
backgrouna begins. Howetrer, the edges do not seem cleer out due to the closeness of hue, value, and/or Intensity. The eye can easily move from one form to another without encourterting boundary 1 ine.

In the wash paintings, Iines have been "drawn" in to solidify the forms, to emphasize the landscape shapea, and to exllven the form by the texture and movement of the Iine. In some cases the diegonal movement of the line atternts to lead the oye in a recessional movenent. This is done by drawing the line from bottom to top, a method of imping plastic space. This method works as indicating plastic space because Ines seen in real landscapo tend to begin at your feet and cowe up to the horizon which is about eye level. An attempt has been made not to organize recessional space into planes but to be experlenced as a homogeneous rocessional movement. The mountain scene in earth colors is an examie of a palnting organized in planes to imply reces sional space. (See page $16 \cdot 2$ ). Mountain stream is an example of an attempt at a totally honogenoous movement in space. (See page 27, a). I feel that a homogeneous recessional movament has a greater lmpact on the viewer because color plays a moxe inportant role in this type of statement. I also believe that color plays a major role In involving a viewer emotionaliy and intellectualiy in a painting. It seems to roe that part of the role of the artist is to dellver messages that can invite others, in some way, to share his 
feeling about the neture of things. For this reason he mat soek a statement that wil have a unfersal expression so that he may communcate with others. This I have tried to do. 


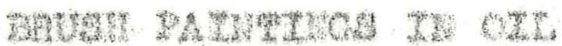

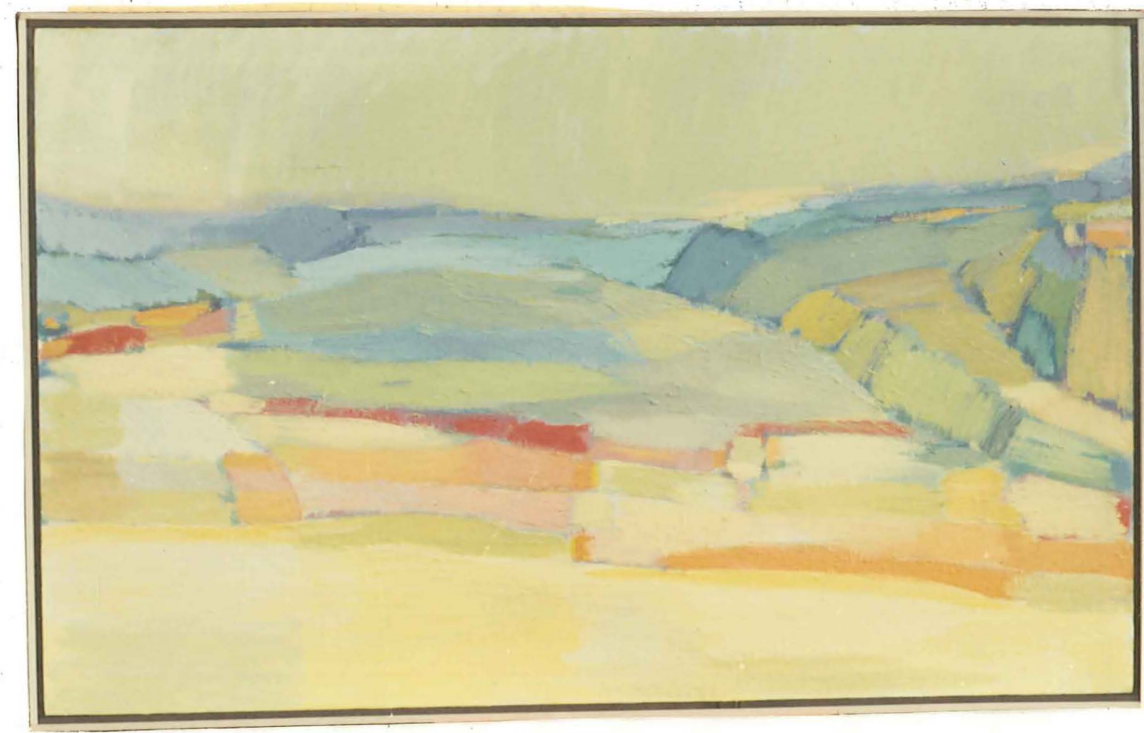

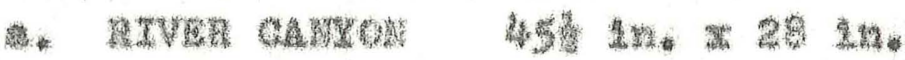

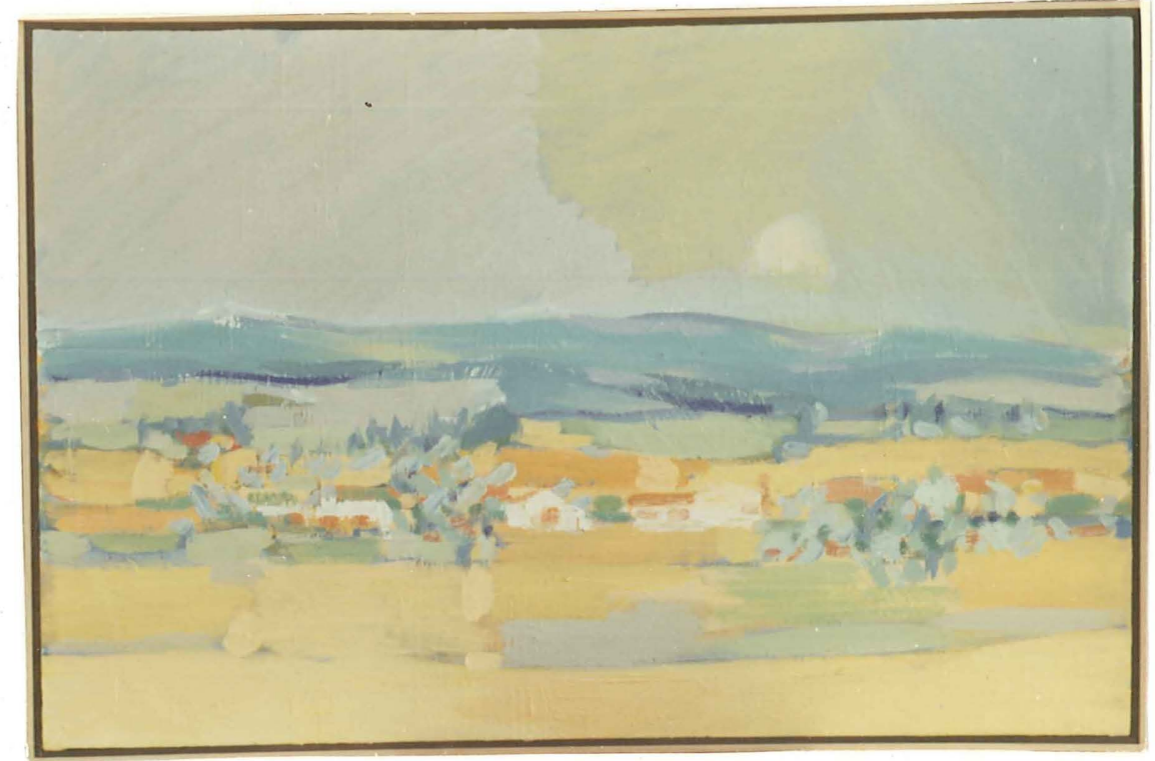

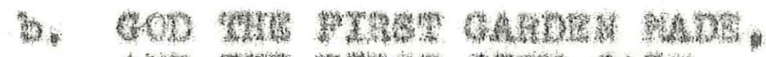

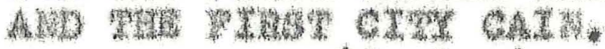

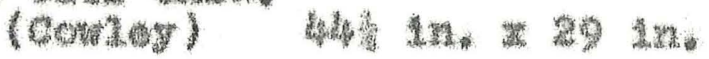




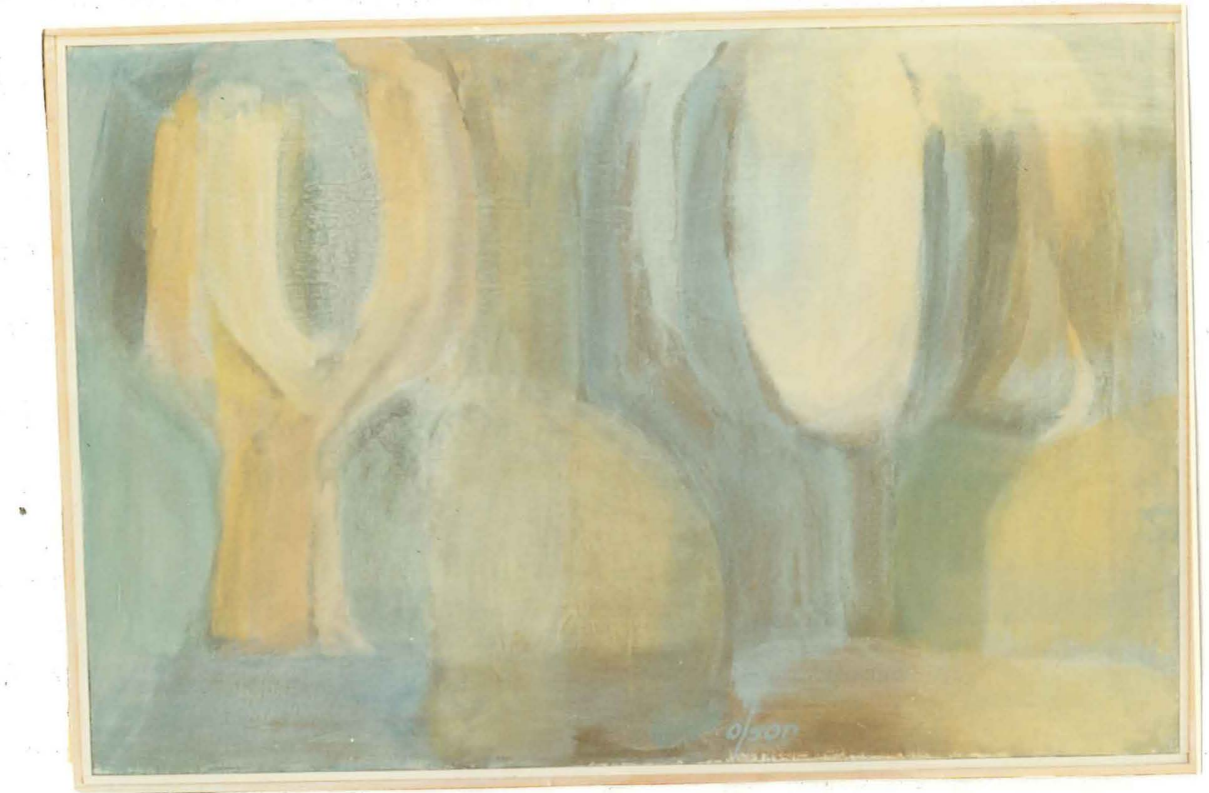

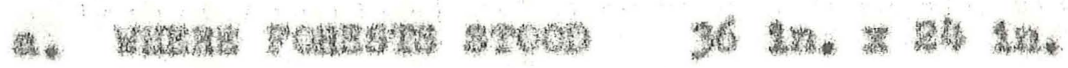

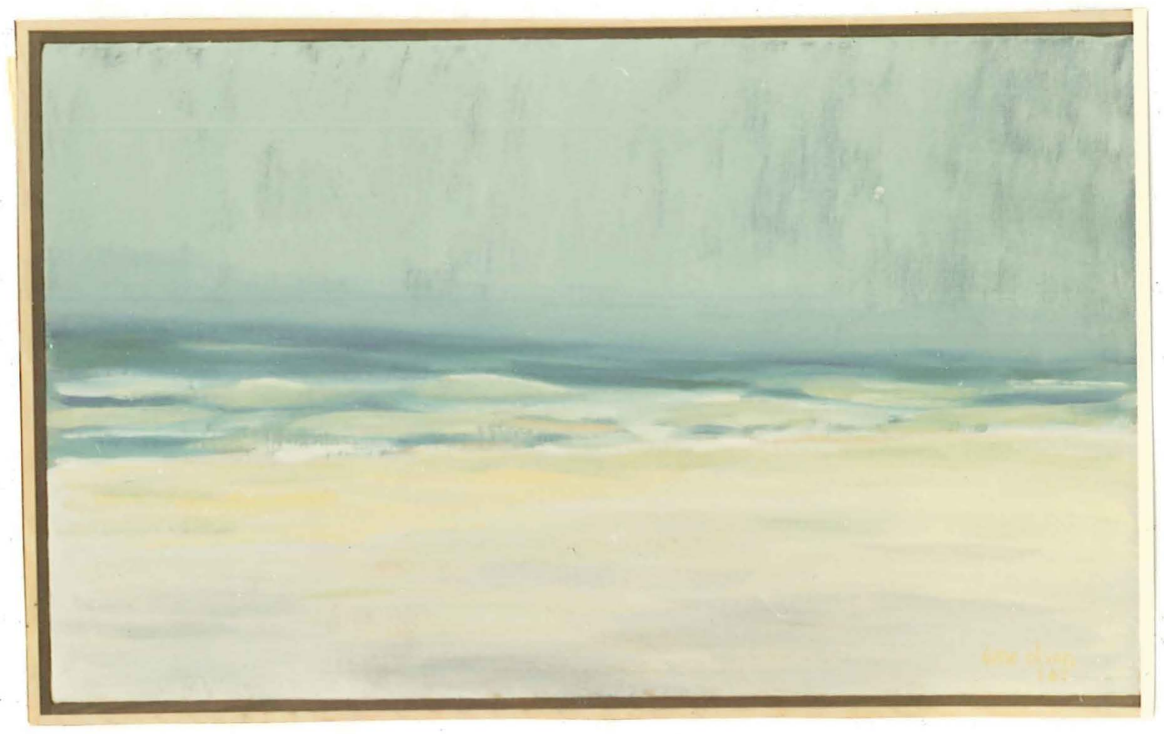

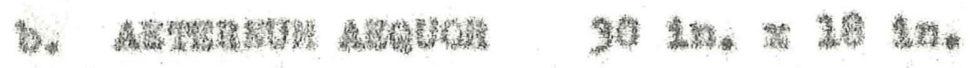




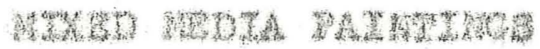

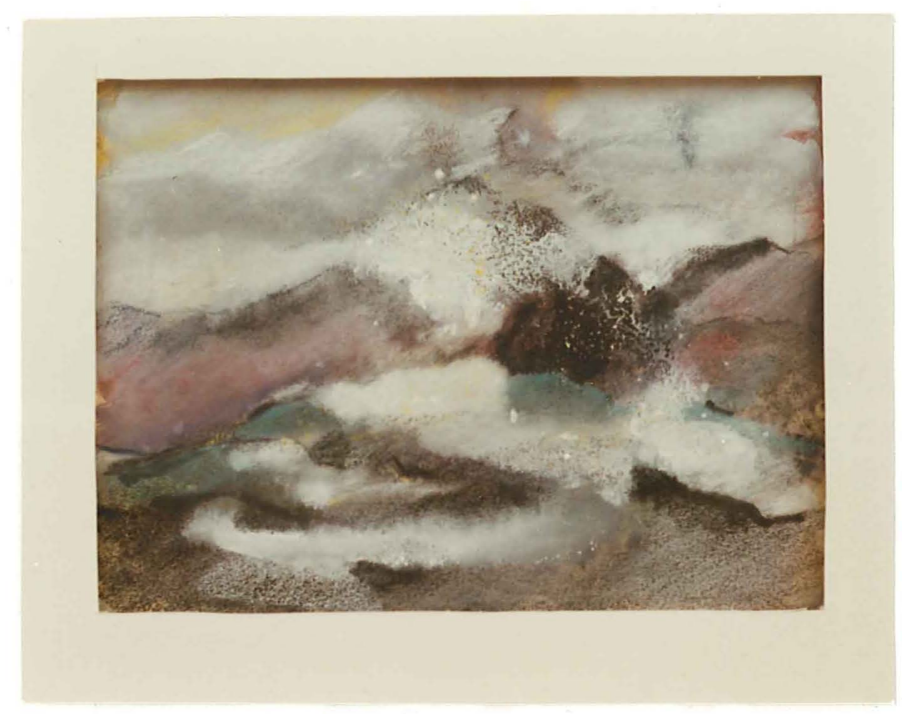

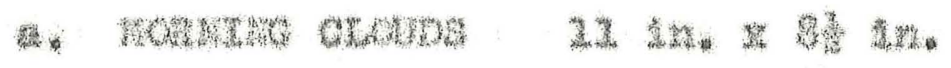

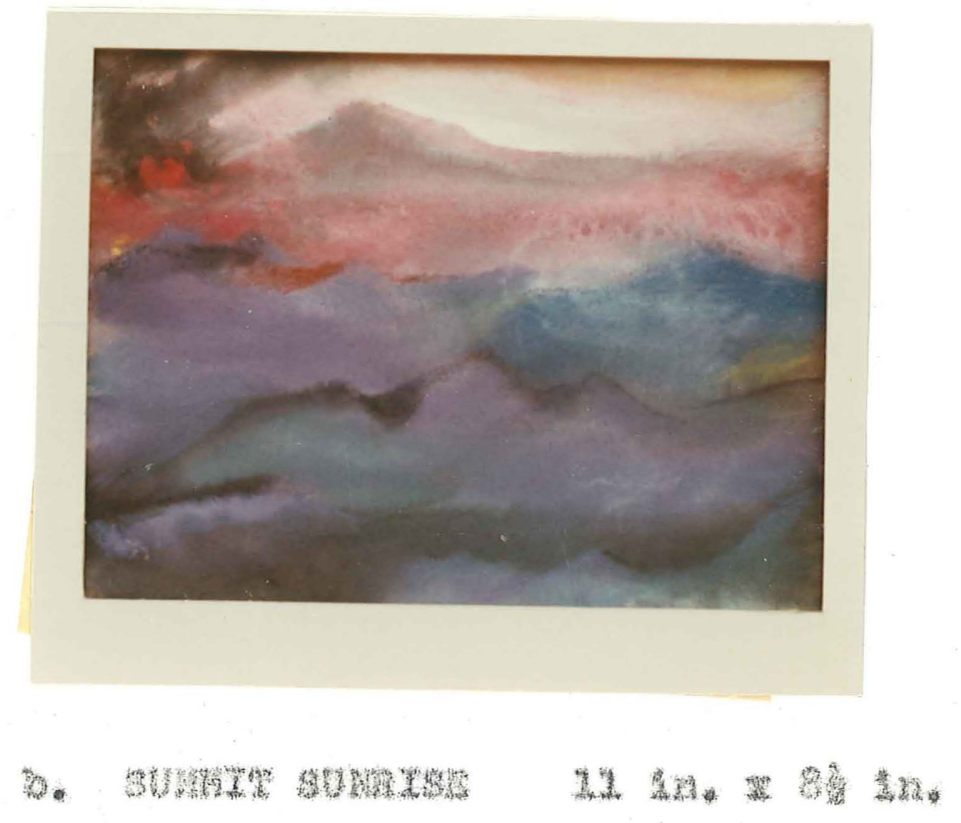




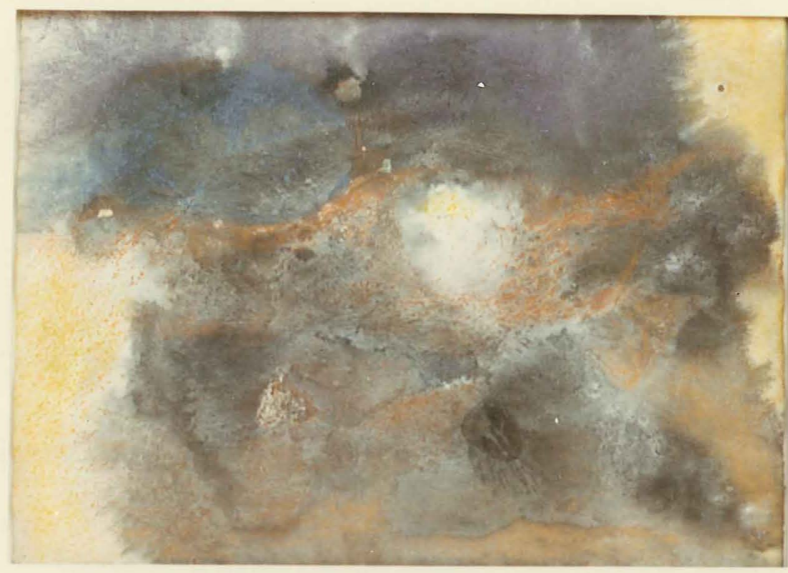

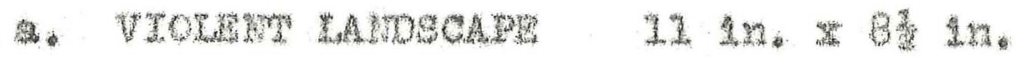

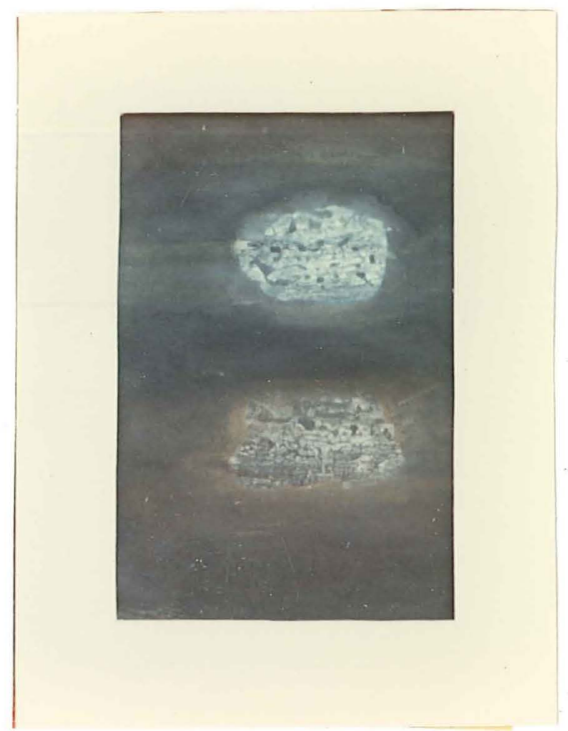

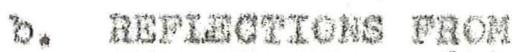

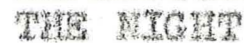
$62 n .2540$ 


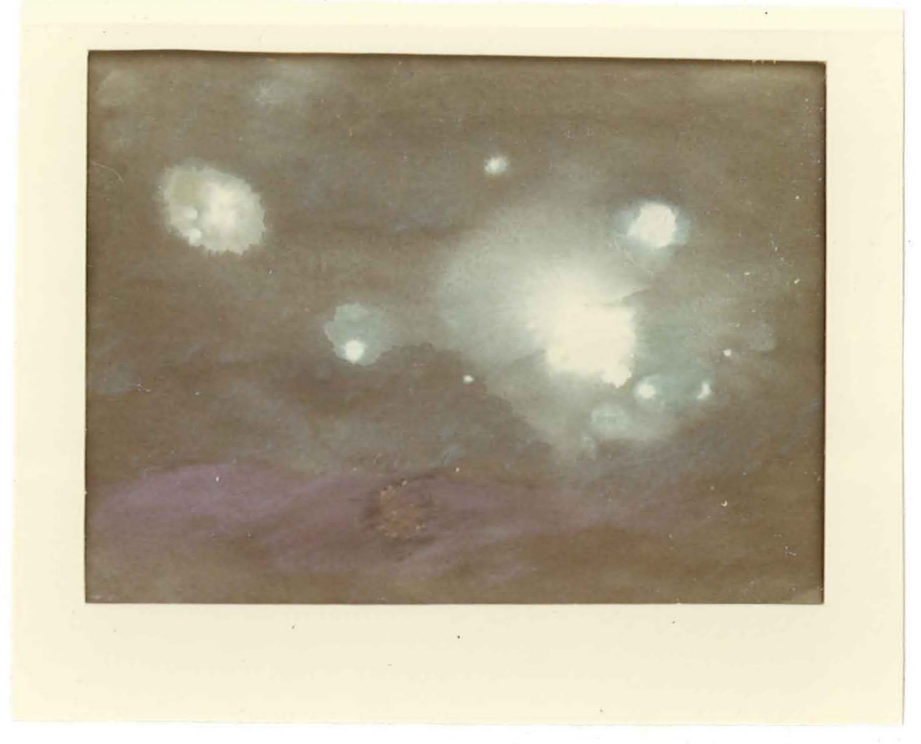

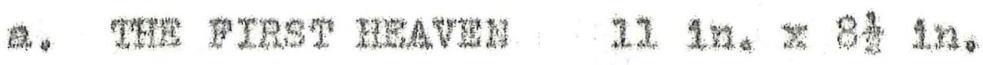
(The furst heaven is of pure sulver. and here the stats are hung out ilice lavps on goldex chaths?

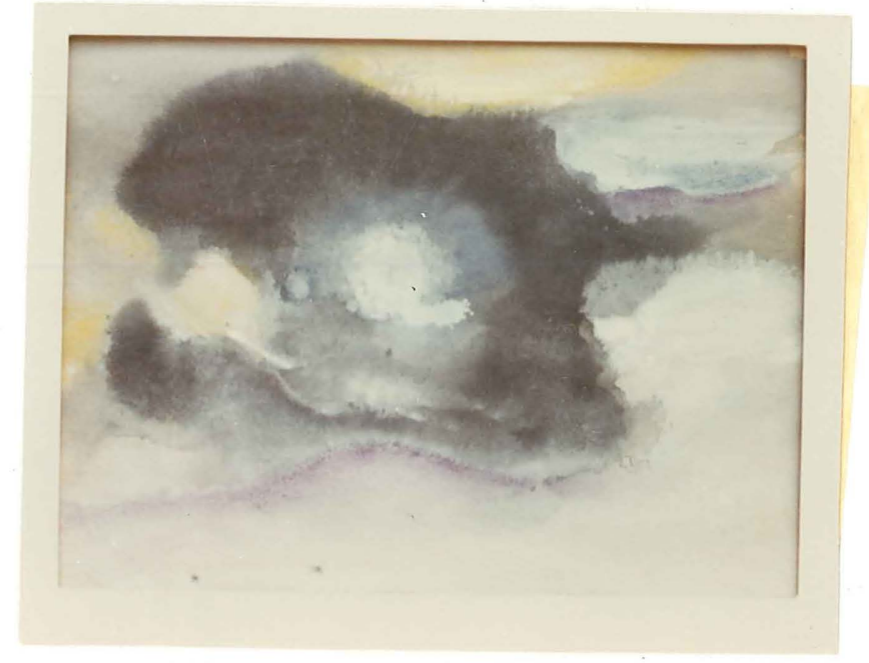

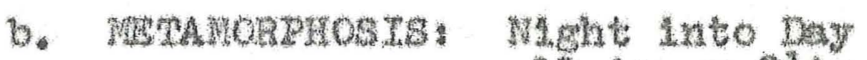

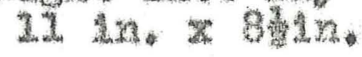




\section{5}

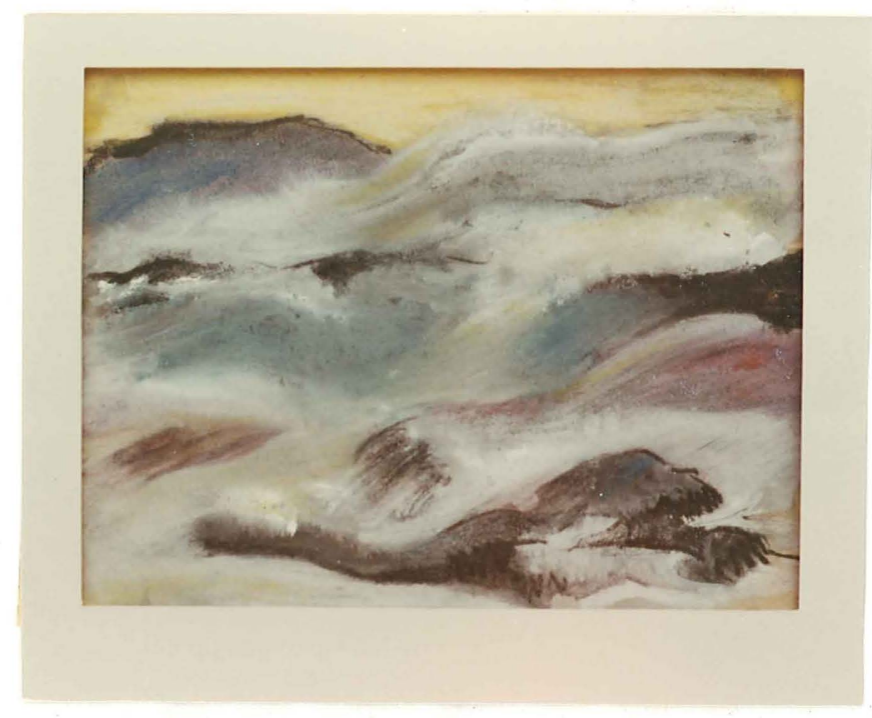

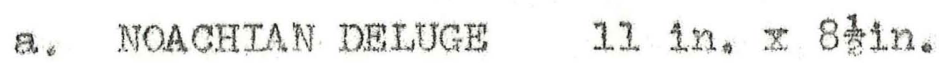

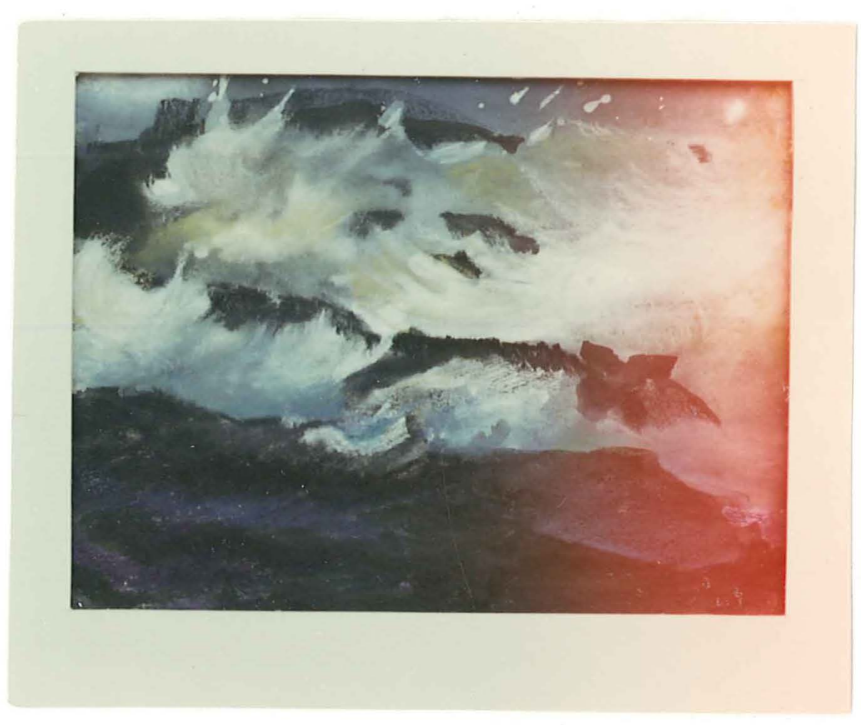

b. TEMPEST 11 In. $\times 8$ 3. 3 . 
WASE PAINTTNOS IN OLL

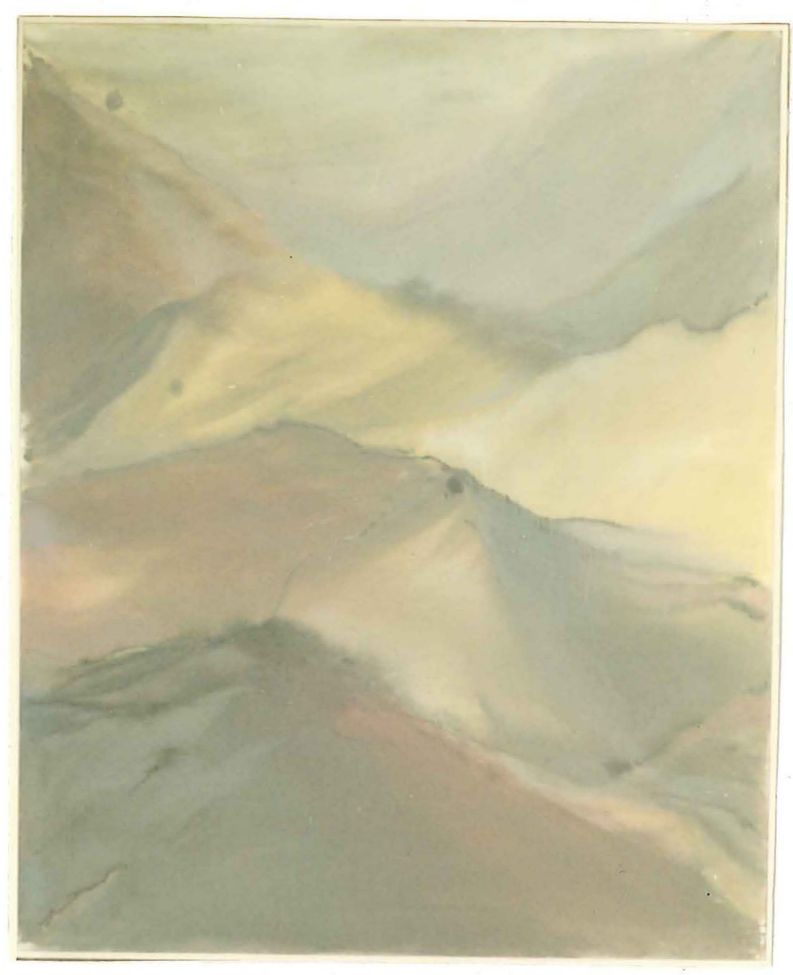

MOUNTATN $47 \mathrm{in} .38 \mathrm{~m}$.

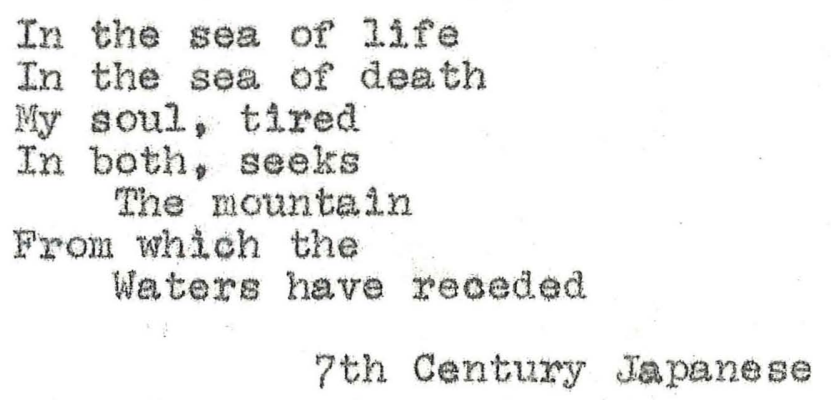




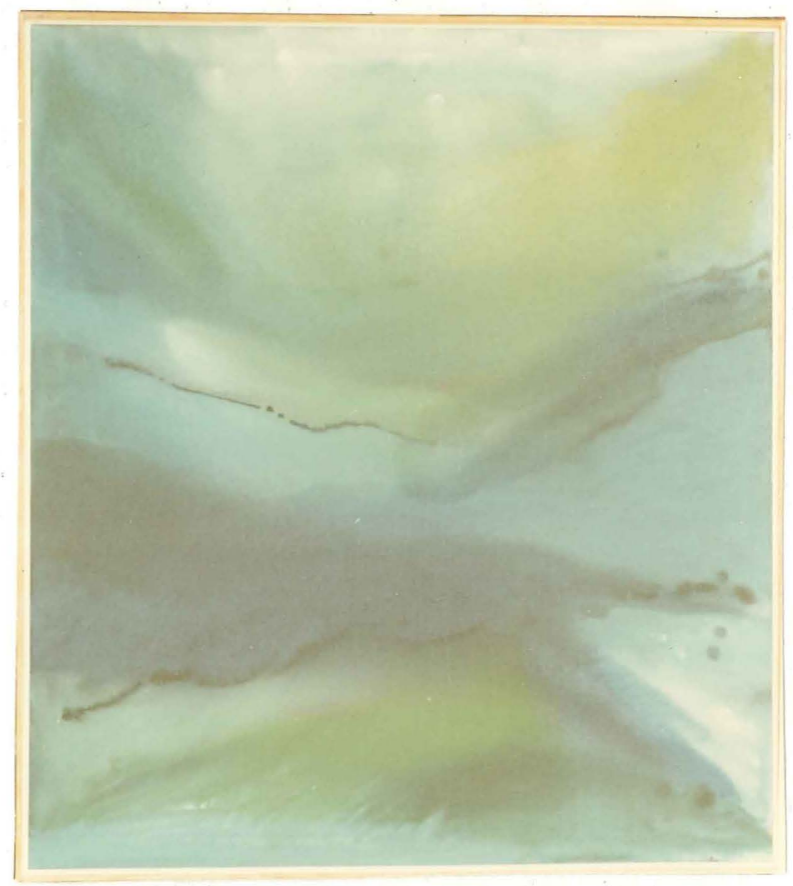

a. MOUNTATN STREAM $45 \frac{1}{2} \mathrm{in} . \mathrm{x} 39 \mathrm{in}$

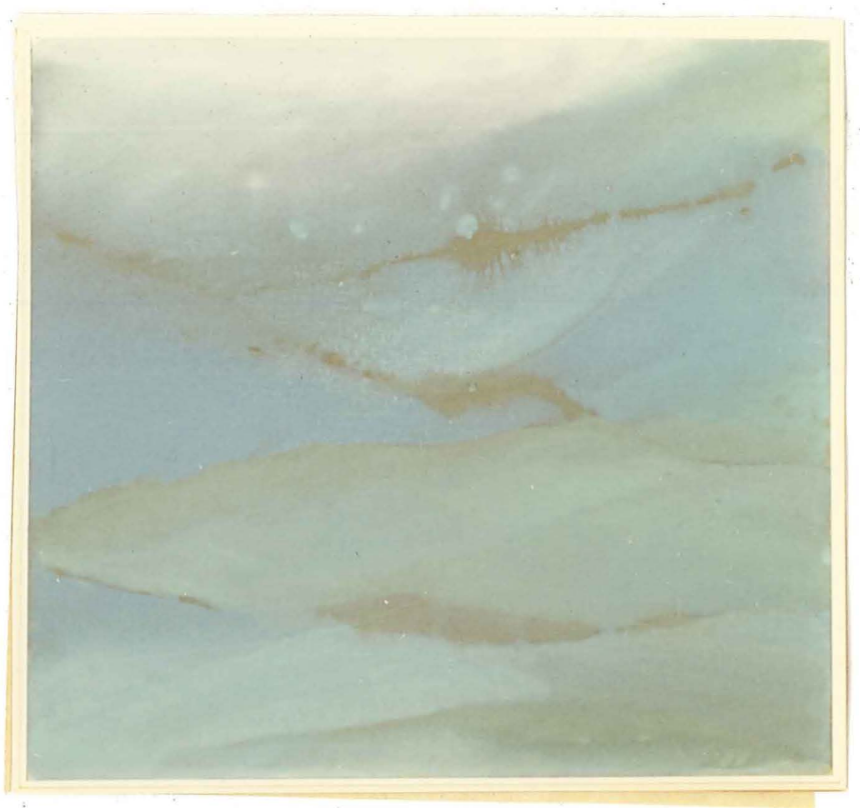

b. CASCADE RECESSES 36 m.x $33 \mathrm{ln}$, 


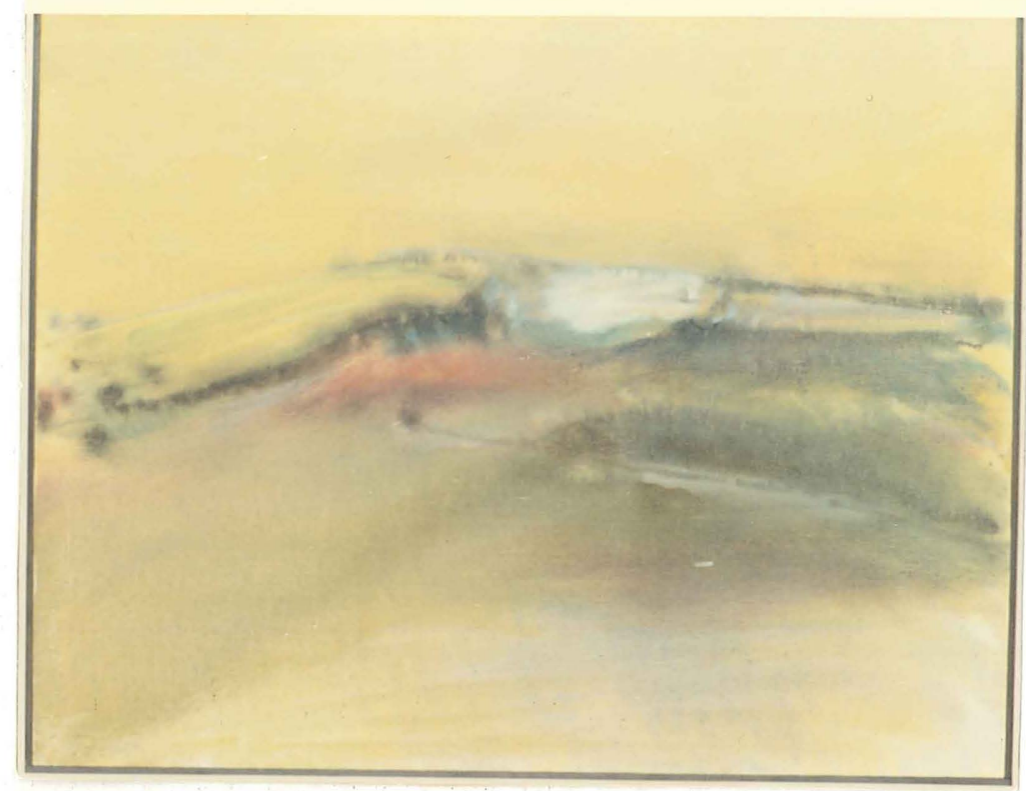

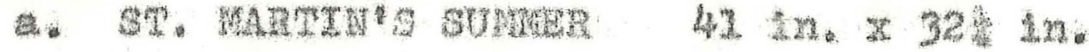

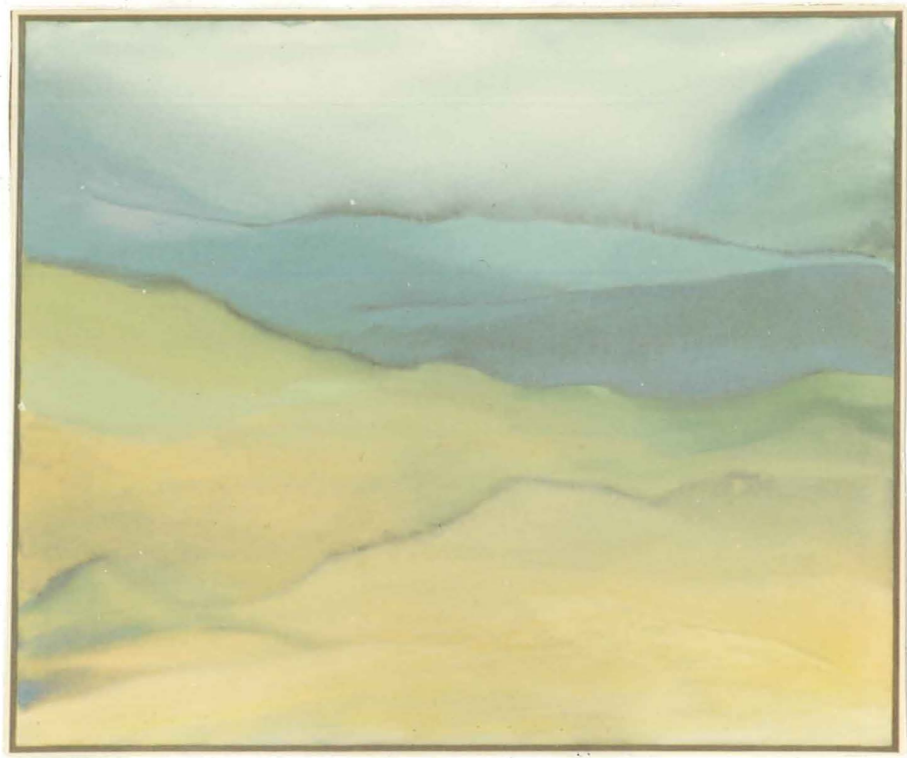

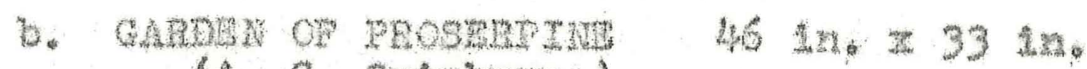
(A. C. Bminburne) 